\title{
Diet of the fishing bat Noctilio leporinus (Linnaeus) (Mammalia, Chiroptera) in a mangrove area of southern Brazil
}

\author{
Marcelo O. Bordignon \\ Departamento de Ciências do Ambiente, Universidade Federal de Mato Grosso do Sul. Caixa Postal 252, 79304-020 \\ Corumbá, Mato Grosso do Sul, Brasil. E-mail: batbull@bol.com.br
}

\begin{abstract}
From January to December 1999, the diet of Noctilio leporinus (Linnaeus, 1758) was determined in a salt-water ecosystem, by analysing the feces of bats captured in mist nets. Of the 61 samples analyzed, most contained remains of fish $(90.2 \%)$, followed by insects $(70.5 \%)$ and crustaceous $(29.5 \%)$. The most frequent fishes species were: silversides Atherinella brasiliensis (Quoy \& Gaimard, 1825), anchovies Cetengraulis edentulus (Cuvier, 1829) and scaly sardines Ophisthonema oglinum (Lesueur, 1818). The most frequent insects were moths (Saturniidae) and beetles (Cerambycidae, Scarabaeidae and Coccinellidae), as well as two species of bat ectoparasites (Streblidae). Among the crustaceous the shrimp (Palaemonidae) and crabs (Gecarcinidae) are was present. The consumption of fish, insects and crustaceans was different for the males and females throughout the year.

KEY WORDS. Piscivorous; sardines.

RESUMO. Dieta do morcego-pescador Noctilio leporinus (Linnaeus) (Mammalia, Chiroptera) em uma área de manguezal do sul do Brasil. De janeiro a dezembro de 1999, foi estudada a dieta de Noctilio leporinus (Linnaeus, 1758) em um ecossistema de manguezal, através da análise das fezes de morcegos capturados com redes-neblina. Das 61 amostras analisadas, a maioria continha fragmentos de peixes $(90.2 \%)$, seguido de insetos $(70.5 \%)$ e crustáceos (29,5\%). As espécies de peixes mais freqüentes foram: peixe-rei Atherinella brasiliensis (Quoy \& Gaimard, 1825), manjuba Cetengraulis edentulus (Cuvier, 1829) e sardinha Ophisthonema oglinum (Lesueur, 1818). Os insetos mais freqüentes foram mariposas (Saturniidae) e besouros (Cerambycidae, Scarabaeidae e Coccinellidae), além de duas espécies de ectoparasitas (Streblidae). Entre os crustáceos, houve a presença apenas de camarões (Palaemonidae) e siris (Gecarcinidae). O consumo de peixes, insetos e crustáceos foi diferente para machos e fêmeas ao longo do ano. PALAVRAS CHAVE. Piscivoria; sardinha.
\end{abstract}

The order Chiroptera contains the greatest variety of feeding habits among the mammals, including particular adaptations, such as sanguivory and piscivory (Ferrarezzi \& Gimenez 1996). Amongst the few piscivorous species, such as Myotis vivesi Menegaux, 1901 (Blood \& Clark 1998), Noctilio leporinus (Linnaeus, 1758) is one of those best adapted to fish eating (Novick \& Dale 1971, Brooke 1994). Known such great bulldog bat or fishing bat, $N$. leporinus is the greater bat of family Noctilionidae, wich includes the lesser buldog bat Noctilio albiventris Desmarest, 1818. The anatomical adaptations of this bat such as greatly elongated feet, claws and calcar of its hind limbs, permit a great efficiency in the capture of fish which are near the water surface (Fish et al. 1991). Provided with an extremely sensitive echolocation system, these bats detect their prey by means of the turbulence arising from shoals of fish at the water surface (SCHNitzler et al. 1994). This bats occurs from Mexico to northern Argentina, included the major river basins such as those of the Amazon and Paraná River in Brazil (DAvIS 1973) and frequently roost in dark caves or hollow trees near rivers, lakes or mangrove ecosystem (Hood \& JONEs JR. 1984). Field works about his diet are not much in neotropic. In the north-east of Brazil, WiLlig (1985) verified that N. leporinus consumed fish and insects, but did not record the species or the frequency with which these items occured in the diet. In Mexico, Cervantes \& Solorzano (1991), analyzing the stomach contents of $23 \mathrm{~N}$. leporinus samples, verified that only six stomachs contained food, showing how difficult it is to study the diet of these animals by means of stomach content. In a more recent study, Brooke (1994) verified in Puerto Rico (Caribbean) that $N$. leporinus consumes approximately 50\% of fish in its diet, as well as insects such as moths and beetles.

Despite the fact that the piscivorous behavior of this bat is known since 1860 (Villa-Ramirez 1966), few studies have tried to quantify the food items which constitute its diet, such as those carried out by BRoокe (1994) in the last years in Puerto Rico. Feces collection of bats which have successfully been to study the diets in tropical biomes, are more common for fruiteating species (SIPINSKI \& Reis 1995, Passos et al. 2003, Passos \& 
Graciolli 2004). However, studies involving the carnivorous or piscivorous species are very limited (NowAK 1994). The more recent studies available in the literature about the diet of $N$. leporinus, use different study methods, such as stomach content analysis of captured bats (CERvantes \& Solorzano 1991) or collection of fecal material deposited in their shelters (BRooKE 1994). The aim of the present study, therefore, was to obtain data about the diet of $N$. leporinus in a salt-water ecosystem on the southern coast of Brazil by collecting and analyzing feces obtained from bats captured during their foraging activities.

\section{MATERIAL AND METHODS}

Guaratuba Bay is on the southern coast of Paraná State $\left(25^{\circ} 50^{\prime} \mathrm{S}, 48^{\circ} 34^{\prime} \mathrm{W}\right)$ and covers approximately $100 \mathrm{~km}^{2}$. The monthly mean water temperature ranges from 16 to $30^{\circ} \mathrm{C}$ during the year and the salinity can be greater than 30\%o (CHAvEs 1995). The place is very much appreciated for subsistence and sport fishing (ChAVEs \& VENDEL 1997), since many marine species spawn in this place, providing a large quantity of alevines during several seasons of the year (CHAves et al. 1998). The regional ichthyofauna is typical of marine and estuarine environments, with species of the Ariidae, Haemulidae, Gerreidae and Sciaenidae families being especially common, as well as the Tetraodontiformes and Pleuronectiformes orders (CHAves 1994).

From January to December 1999, four nights of capture were carried out every month, between 18 and 6:00 h, using three mist nets $2.6 \times 9 \mathrm{~m}$ in size, with a black mesh and $38 \mathrm{~mm}$ in length (model CH9 Avinet, Inc. ${ }^{\circledR}$ ), located perpendicularly to the bank and above the water surface. Each bat captured was placed in a black cotton bag, and remained there until $12 \mathrm{~h}$ the following day, to obtain the feces. These samples were preserved in $10 \%$ formol and later analyzed in the laboratory. Bats were released the night after they were captured, at dusk.

To identify the fish species found in the fecal samples, fishes were collected in the evening of the $2^{\text {nd }}$ May 2000 in the location where the bats were observed foraging, using a manual trawl net $(30 \times 1.20 \mathrm{~m}$ large, and mesh of $0.5 \mathrm{~cm})$. The collected fish scales were compared with those found in the bats' feces. The invertebrates were identified comparing the fragments in the feces with the material of Entomological Collection from the Federal University of Paraná. It was not possible to estimate the number of individuals of each taxon present in the samples due to the large fragmentation of the material.

\section{RESULTS}

Feces samples from 61 individuals were obtained (31 from males and 30 from females), in which 10 families of insects, six of fish and two of crustaceous were recorded. Among the taxa encountered, fish occurred with a greater frequency, followed by insects and crustaceans (Tab. I). Of the 55 samples containing fish, the silverside Atherinella brasiliensis (Quoy \& Gaimard, 1825) of the Atherinopsidae family was the most frequent, fol-
Table I. Fish and invertebrates encountered in the feces $(n=61)$ of Noctilio leporinus from Guaratuba bay, during 1999. (\%) is the relative frequency; $(n)$ is the total number of samples which the taxa was identified.

\begin{tabular}{|c|c|c|}
\hline Taxon & $(\%)$ & (n) \\
\hline Teleostei & 90,2 & 55 \\
\hline \multicolumn{3}{|l|}{ Atherinopsidae } \\
\hline Atherinella brasiliensis (Quoy \& Gaimard, 1825) & 34,4 & 21 \\
\hline \multicolumn{3}{|l|}{ Mugilidae } \\
\hline $\begin{array}{l}\text { Mugil curema (Valenciennes in Cuvier \& } \\
\text { Valenciennes, 1836) }\end{array}$ & 27,9 & 17 \\
\hline \multicolumn{3}{|l|}{ Engraulidae } \\
\hline Cetengraulis edentulus (Cuvier, 1829) & 16,4 & 10 \\
\hline \multicolumn{3}{|l|}{ Clupeidae } \\
\hline Opisthonema oglinum (Lesueur, 1818) & 14,8 & 9 \\
\hline Harengula clupeola (Cuvier, 1829) & 9,8 & 6 \\
\hline Pellona harroweri (Fowler, 1917) & 3,3 & 2 \\
\hline \multicolumn{3}{|l|}{ Centropomidae } \\
\hline Centropomus parallelus Poey, 1860 & 4,9 & 3 \\
\hline \multicolumn{3}{|l|}{ Carangidae } \\
\hline Chloroscombrus chrysurus (Linnaeus, 1766) & 1,6 & 1 \\
\hline Insecta & 70,5 & 43 \\
\hline \multicolumn{3}{|l|}{ Coleoptera } \\
\hline Cerambycidae & 13,1 & 8 \\
\hline Scarabaeidae & 4,9 & 3 \\
\hline Coccinellidae & 1,6 & 1 \\
\hline \multicolumn{3}{|l|}{ Lepidoptera } \\
\hline Saturniidae & 37,7 & 23 \\
\hline \multicolumn{3}{|l|}{ Hymenoptera } \\
\hline Formicidae & 8,2 & 5 \\
\hline Braconidae & 4,9 & 3 \\
\hline Ichneumonidae & 4,9 & 3 \\
\hline \multicolumn{3}{|l|}{ Diptera } \\
\hline Simuliidae & 6,6 & 4 \\
\hline Ceratopogonidae & 1,6 & 1 \\
\hline \multicolumn{3}{|l|}{ Streblidae } \\
\hline Paradyschiria fusca Speiser, 1900 & 9,8 & 6 \\
\hline Noctiliostrebla aitkeni Wenzel, 1966 & 1,6 & 1 \\
\hline Crustacea & 29,5 & 18 \\
\hline \multicolumn{3}{|l|}{ Decapoda } \\
\hline Palaemonidae & 24,5 & 15 \\
\hline Gecarcinidae & 4,9 & 3 \\
\hline \multicolumn{3}{|l|}{ Aracnida } \\
\hline Acarina & 6,6 & 4 \\
\hline
\end{tabular}

lowed by the silver mullet Mugil curema Valenciennes in Cuvier \& Valenciennes, 1836 (Mugilidae), sardines (Clupeidae) and anchovies (Engraulidae). The fat snook or robalito Centropomus parallelus Poey, 1860 (Centropomidae) and bumper Chloroscom- 
brus chrysurus (Linnaeus, 1766) (Carangidae) were the least frequently represented in the $N$. leporinus feces. Most of the samples collected $(68.75 \%)$ contained only one species of fish, while 14 samples $(29.16 \%)$ contained two species and only one sample (2.08\%) contained three different fish species.

Of the $43 \mathrm{~N}$. leporinus feces samples containing insects, moths were the most frequent. Similarly to the crustaceans, most of the Lepidoptera (Saturniidae) were very fragmented, thereby making a more precise identification impossible. Among the beetles, fragments of Cerambycidae, Scarabaeidae and Coccinellidae were identified. Hymenoptera fragments of the Formicidae, Braconidae and Ichneumonidae families were also encountered, as well as Diptera of the Simuliidae and Ceratopogonidae families, and whole specimens of ectoparasites of the Streblidae family. Non-identified specimens of mites (Acarina) were also recorded. Of the 18 samples containing crustaceou fragments, these withe shrimps of the Palaemonidae family had a greater frequency and while crabs of the family Gecarcinidae occurred in low frequence in feces.

The fish, insect and crustaceous frequencies recorded in the feces samples of captured $N$. leporinus varied throughout the year (Fig. 1). Fish were present throughout the year, with an average monthly frequency of $92.47 \%$. In winter (from July to September), fish were present in $100 \%$ of the fecal samples. The average monthly frequency of insects sampled was of $67.43 \%$, showing a greater frequency variation during the year. At the beginning of the colder period (May), a decline in the frequency of this item was observed in the N. leporinus feces, varying from $40 \%$ (June) to $20 \%$ (July), being absent from August to October. In the spring, when the temperatures rise again, they started appearing once more. The crustaceous were present with a frequency which varied from $20 \%$ to $50 \%$ in the feces collected during the year. This item was absent in the feces samples collected in May and from August to November. The average monthly frequency of crustaceous sampled was of $34.46 \%$.

The males consumed fish throughout the year, with a smaller frequency from January to June. There was an absence of fish in the females' diets from October to December, being present however in the other months. The consumption of insects by the males was smaller from July to September than during the other months of the year. Among the females, the greater frequency of insects in the diet occurred from October to December, maintaining an average of 50\% in the other months of the year. The consumption of crustaceous by the males was not greater than $40 \%$ of the total number of samples collected, except for from April to June, when they were absent. In the females' diet, the crustaceous were absent from October to December, with a frequency not greater than $30 \%$ during the other months.

\section{DISCUSSION}

The data obtained in this study show that the ichthyofauna present in the N. leporinus diet is varied. Quantitatively, this result was similar to that obtained by BRоок (1994), who

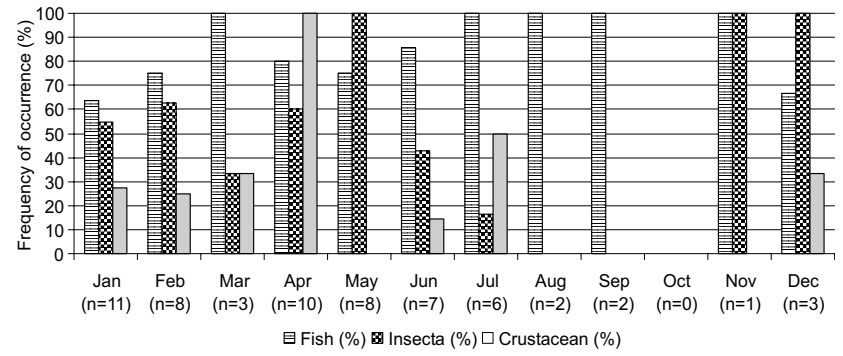

Figure 1. Fish, crustaceous and insects presents in diet of Noctilio leporinus captured in Guaratuba Bay during 1999, based on 61 feces samples.

recorded eight fish species from eight different families in Porto Rico. Qualitatively, however, the fish species present in the diets were different, even though both studies presented the Atherinopsidae and Clupeidae families in the N. leporinus diet. This must be due to the particularities of the ichthyofauna in each study location.

The Mugilidae, Centropomidae and Carangidae families identified in the bats of Guaratuba were not encountered in BRookE's study (1994). On the other hand, the Cichlidae Mozambique mouthbrooder Oreochromis mossambicus (Peters, 1852), Holocentridae dusky squirrelfish Sargocentron vexillarium Poey, 1860, Gerreidae yellowfin mojarra Gerres cinereus (Walbaum, 1792), Sphyraenidae great barracudas Sphyraena barracuda (Edwards in Catesby, 1771) and Exocetidae ballyhoo Hemiramphus brasiliensis (Linnaeus, 1758) families encountered by Ввоок (1994) were not present in this study, despite the Gerreidae and Exocetidae families also being present in Guaratuba Bay.

The most frequent fish in the N. leporinus diet in Guaratuba was silverside Atherinella brasiliensis (Quoy \& Gaimard, 1824) (Atherinopsidae) (38.18\%), while BRоOKE (1994) obtained $52.0 \%$ for another species the hardhead silverside Atherinomorus stipes (Muller \& Trotshel, 1848) in Porto Rico. After Atherinopsidae, the most frequent families in the $N$. leporinus diet in Guaratuba were Mugilidae and Clupeidae, both with 30.9\%, while in Brooke's study (1994) it was Cichlidae (42.0\%), represented by $O$. mossambicus.

Both in Guaratuba and Porto Rico, N. leporinus has a large variety of fish to choose from throughout the year. However, the size of the preys certainly is not greater than $15 \mathrm{~cm}$ in length, as observed by BROOKE (1994) and BordignON (in press). Therefore, the variety and availability of shoals of these fish, which are usually formed of juveniles, will determine whether $N$. leporinus captures more or less of them. This conclusion is based on the fact that the fishing behavior of this bat depends on the presence and density of its prey in foraging areas (ROMERo 1985). Both Veysey et al. (2000) in Costa Rica and Bordignon (in press) in Brazil was observed that foraging behavior of $N$. leporinus is conditioned to displacement of fish shoals in estuarines bays along of a tide level variation. The Atherinidae, Mugilidae, Engraulidae and Clupeidae species are fish which group together

Revista Brasileira de Zoologia 23 (1): 256-260, março 2006 
in shoals, moving close to the surface. The typical behavior of these species therefore makes them vulnerable prey for the strategy used by $N$. leporinus when capturing fish, since it uses an acute method of echolocation to detect shoals of fish which move close to the surface (Altenbach 1989, Brooke 1994).

The frequency of moths in the feces of $N$. leporinus from Guaratuba Bay (36.5\%) was greater than that recorded in Porto Rico (19.8\%) by Brooke (1994). On the other hand, the order Coleoptera represented $19.9 \%$ in the present study, compared with 36.0\% obtained by BROOKE (1994). The frequency of crustaceous encountered in Guaratuba (28.57\%) was also greater than the average of $2.3 \%$ recorded in Porto Rico (BROOKE 1994).

Species of the Streblidae family are common ectoparasites in neotropical bat populations (WENZEL 1976, Guerrero 1996, Moura et al. 2003, Graciolli 2004). However, there are no records in the literature about the presence of ectoparasites in the feces of $N$. leporinus. It is possible that the samples of ectoparasites encountered in this study were probably ingested accidentally during body-cleaning activities.

The reduction in the frequency of insects in the feces of $N$. leporinus between June and September (austral winter), could be related to the low availability of this food item, since insects are less active in periods of low temperature. It was possible to observe that female $N$. leporinus only consumed insects during the spring (from October to December), which was different to the males, that consumed insects, fish and crustaceans in the same period. Studies do not exist to explain this difference. However, it is possible that since the insects are easy to capture, the females prefer to eat this item instead of fish so that they can return to their shelter more quickly to feed their offspring, since most of the females are lactating in the spring and summer (Hood \& JoNes JR 1984, NowAK 1994).

One of the problems faced by studies about bats' diets when samples are obtained in bat guano deposits, which exist in their shelters, is the impossibility to compare individuals and the sexes. In adition Noctilio leporinus can be found together with other species of bats in the same shelter (HOOD \& JONES JR. 1984, Nogueira \& Pol 1998, Rodriguez-Duran 1998), resulting in sample failure since the feces of other species could be mixed together with that deposited by N. leporinus. The collection of feces directly from the captured bats carried out in Guaratuba Bay tried to obtain individual samples according to the sex and time of year, with the aim of obtaining more precise information about the diet of this species in its feeding location.

In this study, however, it was possible to determine that male and female $N$. leporinus present different feeding habits, and they also use the food sources in different ways throughout the year, whether they are fish, insects or crustaceans.

\section{ACKNOWLEDGMENTS}

I'm indebt to my wife Adrina de Oliveira França for laboratory and fielworks assistance and the Iate Clube de Caiobá board of directors for help in field works. I'm also greatfull to
Fundação "O Boticário de Proteção à Natureza", to Curso de Pos-Graduação em Zoologia (UFPR) and to CAPES/CNPq for the logistics and financial support during the fieldworks. Special thanks to Emygdio L.A. Monteiro Filho, Fernando C. Passos, Mirna M. Casagrande, Kesa Lehti and Fernando C.W. Rosas for their suggestions and revision of the manuscript.

\section{REFERENCES}

Altenbach, J.S. 1989. Prey capture by the fishing bats Noctilio leporinus and Myotis vivesi. Journal of Mammalogy, Lawrence, 70: 421-424.

Blood, B.R. \& M.K. Clark. 1998. Myotis vivesi. Mammalian Species, Northampton, 588: 1-5.

Bordignon, M.O. 2006. Padrão de atividade e comportamento de forrageamento do morcego-pescador Noctilio leporinus (Linnaeus, 1758) (Chiroptera, Noctilionidae) na Baía de Guaratuba, Paraná, Brasil. Revista Brasileira de Zoologia, Curitiba, 23 (1): 50-57.

Brooke, A.P. 1994. Diet of the fishing bat, Noctilio leporinus (Chiroptera: Noctilionidae) Journal of Mammalogy, Lawrence, 75: 212-218.

Chaves, P.T.C. 1994. A incubação de ovos e larvas em Genidens genidens (Valenciennes) (Siluriformes, Ariidae) da Baía de Guaratuba, Paraná, Brasil. Revista Brasileira de Zoologia, Curitiba, 11 (4): 641-648.

Chaves, P.T.C. 1995. Atividade reprodutiva de Bairdiella ronchus (Cuvier) (Pisces, Sciaenidae) na Baía de Guaratuba, Paraná, Brasil. Revista Brasileira de Zoologia, Curitiba, 12 (4): 759 766.

Chaves, P.T.C. \& A.L. Vendel. 1997. Reprodução de Stellifer rastrifer (Jordan) (Teleostei, Sciaenidae) na Baía de Guaratuba, Paraná, Brasil. Revista Brasileira de Zoologia, Curitiba, 14 (1): 81-89.

Chaves, P.T.C.; A. Rickli \& J.L. Bouchereau. 1998. Stratégie d'occupation de la mangrove de la baie de Guaratuba (Brésil) par le Sciaenidae prédateur Isopisthus parvipinnis (Teleostei, Pisces). Cahiers de Biologie Marine, Roscoff, 39: 63-71.

Cervantes, M.A. \& T.A. Solorzano. 1991. Notas sobre la dieta alimenticia del murcielago pescador Noctilio leporinus (Mammalia: Chiroptera). Anales de la Escuela Nacionale de Ciencias Biologicas del México, México, 35: 123-127.

DAvIs, W.B. 1973. Geographic variation in the fishing bat, Noctilio leporinus. Journal of Mammalogy, Lawrence, 54: 862-874.

Ferrarezzi, H. \& E.A. Gimenez. 1996. Systematic Patterns and the evolution of feeding habits in Chiroptera (Archonta: Mammalia). Journal of Comparated Biology, London, 1: 75-94.

Fish, F.E.; B.R. Blood. \& B.D. Clark. 1991. Hydrodynamics of the feet of fish-catching bats: influence of the water surface on drag and morphological design. Journal of Experimental Zoology, New Haven, 258: 164-173.

Graciolli, G. 2004. Nycteribiidae (Diptera, Hippoboscoidea) no Sul do Brasil. Revista Brasileira de Zoologia, Curitiba, 21 (4): 971-985.

Revista Brasileira de Zoologia 23 (1): 256-260, março 2006 
Guerrero, R. 1996. Streblidae (Diptera: Pupipara) parásitos de los murciélagos de Pakitza, Parque Nacional Manu (Perú), p. 627-641. In: D.E. Wilson \& A. SANDOval (Eds). Manu: la biodiversidad del sureste del Perú. Washington, Smithsonian Institution Press, 679p.

Hood, C.S. \& J.K. Jones JR. 1984. Noctilio leporinus. Mammalian Species, Northampton, 216: 1-7.

Moura, M.O.; M.O. Bordignon \& G. Graciolli. 2003. Host Characteristics do not affect community structure of ectoparasites on the fishing bat Noctilio leporinus (L., 1758) (Mammalia: Chiroptera). Memórias do Instituto Oswaldo Cruz, Rio de Janeiro, 98 (6): 811-815.

Nogueira, M.R. \& A. Pol. 1998. Observações sobre os hábitos de Rhynchonycteris naso (Wied-Neuwied, 1820) e Noctilio albiventris Desmarest, 1818 (Mammalia, Chiroptera). Revista Brasileira de Biologia, Rio de Janeiro, 58: 473-480.

Novick, A. \& B.A. Dale. 1971. Foraging behavior in fishing bats and their insectivorous relatives. Journal of Mammalogy, Lawrence, 52: 817-818

NowAK, R.M. 1994. Walker's bats of the world. London, The Johns Hopkins University Press, 866p.

Passos, F.C.; W.R. Silva; W.A. Pedro \& M.R. Bonin. 2003. Frugivoria em morcegos (Mammalia, Chiroptera) no Parque Estadual Intervales, sudeste do Brasil. Revista Brasileira de Zoologia, Curitiba, 20 (3): 511-517.

Passos, F.C. \& G. Graciolli. 2004. Observações da dieta de Artibeus lituratus (Olfers) (Chiroptera, Phyllostomidae) em duas áre- as do sul do Brasil. Revista Brasileira de Zoologia, Curitiba, 21 (3): 487-489.

Rodriguez-Duran, A. 1998. Nonrandom aggregations and distribution of cave-dwelling bats in Puerto Rico. Journal of Mammalogy, Lawrence, 79: 141-146.

Romero, A. 1985. Cave colonization by fish: role of bat predation. The American Midland Naturalist, Notre Dame, 113: 7-12.

Schnitzler, H.U.; E.K.V. Kalko; I. Kaipf \& A.D. Grinnell. 1994. Fishing and echolocation behavior of the greater bulldog bat, Noctilio leporinus, in the field. Behavior Ecology and Sociobiology, Berlin, 35: 327-345.

SiPINSKI, E.A.B. \& N.R. ReIs. 1995. Dados ecológicos dos quirópteros da Reserva de Volta Velha, Itapoá, Santa Catarina, Brasil. Revista Brasileira de Zoologia, Curitiba, 12 (3): 519-528.

Veysey, J.S.; J.A. Macintosh; K.W. Manaras \& C.B. Shannon. 2000. The effects of time and tide on foraging behavior of the piscivorous bulldog bat. The Dartmouth Undergraduate Journal of Science, Hanover, 2 (3): 36-40.

Villa-Ramirez, B. 1966. Los murcielagos de México. Mexico, Editorial Libros de México, 347p.

Wenzel, R.L. 1976. The streblid batflies of Venezuela (Diptera: Streblidae). Brigham Young Univiversity Science Bulletin, Provo, 20: 1-117.

WiLLIG, M.R. 1985. Reproductive patterns of bats from caatingas and cerrado biomes in northeast Brazil. Journal of Mammalogy, Lawrence, 66: 668-681.

Recebido em 06.IV.2005; aceito em 23.XI.2005. 